\title{
Metaphor Symbols in Javanese Traditional Expression As Manifestation of the Cultural Heritage in Javanese Community
}

\author{
F Kurwidaria, A A Rahadini, K D Wijayanti \\ Universitas Sebelas Maret, Surakarta, Indonesia \\ favorita.kurwidaria282@gmail.com
}

\begin{abstract}
The Javanese traditional expression is one of the Javanese cultural heritage enriched by the value of the beauty of the language as well as the cultural local wisdom. The Javanese traditional expression generally contains the principle, guideline, and the value adhered by the Javanese community. Javanese community is known by its character of sinamun ing samudana meaning 'hidden in figure of speech' and tanggap ing sasmita meaning 'responsive to signs', so the Javanese expression mostly contains figure of speech, connotation, and the comparison form/metaphor. As a result, the meaning requires the process of understanding as well as in-depth interpretation. Therefore, the aims of this research are to identify as well as to understand the aspect of metaphor symbol used in the Javanese traditional expression, to find out the relation between metaphor symbol used in the meaning, and to determine the factor underlain the emergence of the expression forms in the community. This research employed ethnolinguistic approach investigating the relation between language and the culture in the society which is supported by other theories such as semantic and semiotic in accordance with the aspect of meaning. The result of the analysis is expected to give the explanation about the meaning of Javanese traditional expression. Thus, the value of cultural local wisdom is probed to keep preserving the sustainability of the Javanese verbal tradition.
\end{abstract}

Keywords: Metaphor Symbols; Javanese Traditional; Cultural Heritage; Verbal Tradition. 


\section{INTRODUCTION}

The traditional Javanese expression is one form of verbal expression of Javanese people who are rich in the value of local cultural wisdom. The substance of meaning contained in Javanese traditional expressions is inseparable from the views of life, the system of values, principles, and the local wisdom of the creator's culture. Endraswara once reviewed Javanese ethnopsychology which states that Javanese people are known for their veiled nature "nggone semu' "if they express something not openly -, sinamun ing samudana 'closed with disguised words", sesadone ingadu manis 'any problem is faced with a sweet face'. The broader meaning is that Javanese thinking and behavior are not always open or tend to be symbolic. Its full of figures of speech and symbolism. Often many things are spoken not blatantly or sinamudana "disguised" [1]. In addition, Javanese is also tanggap ing sasmita 'response to signs' in understanding existing phenomena. This is reflected in the way the Javanese people express something, that is sometimes not directly, but through speech which is wrapped up in metaphors, connotations, parables and metaphorical expressions. One such form can be found in traditional Javanese expressions.

Javanese parents in providing advice and knowledge to their offspring often use this form of traditional expression. This traditional Javanese expression can be interpreted as an expression whose composition of the language is fixed, and generally accompanied by connotations, habits, and comparisons. Comparisons that are used can be derived from the results of observations and contemplation of the people of the past on the phenomena of human life, objects, along with other living things that exist in the universe. This phenomenon is then used as a symbol or symbol of the nature, character and behavior of humans in their lives. Thus it can be said that various of these phenomena can be the basis for the creation of traditional expressions, wherein later the traditional Javanese expression is packaged in the form of a metaphor

Previous studies of metaphors or proverbs have been conducted by Wei Lixia and Wong Bee Ing, who have specified their studies on the metaphor of snake, in British and Chinese culture. In their analysis they argue that the characteristics or other similarities inherent in these animals can be used as the basis for the creation of metaphors[2]. Furthermore, there is a study of metaphor by Vengadasamy literary work, which is based on Lakoff and Johnson's conceptual metaphor theory. Lakoff and Johnson assert that metaphors are analogous in nature that means that there is a set of correspondences between two concepts in two different domains of knowledge. Therefore in the structure of the metaphor there are two components, namely the source domain and the target domain [3]. To be able to know the meaning in the symbol of a metaphor, it is necessary to know the form of similarities between the characteristics of the target and the source. Furthermore, by comparing the two, you will find the basis of using the metaphor[4].

The form of the metaphor that is constructed often uses certain symbols based on the long experience and the socio-cultural background of the creator. This is in line with what was revealed by Herusatoto that human think, feel and behave with symbolic expressions[5]. The symbol can be interpreted as a word, sign or signal, which is used to represent something else including meaning, quality, abstract, ideas, objects. Based on the symbols in traditional expressions, S.Keyzer classifies Javanese proverbs into five types, namely: (1) proverbs concerning animals, (2) proverbs about plants, (3) proverbs about humans, (4) proverbs 
concerning members of relatives, and (5) proverbs regarding limb functions. In fact, the traditional expression in Javanese society has a proverb that includes the five groups[6].

In the process of creating traditional expressions, it is certainly inseparable from the process of appreciation and observation of the creator society towards the phenomena that are around them, both the nature of human activities, animals, plants and other natural objects. This phenomenon is then related to the nature or behavior of human life. Therefore it is necessary to understand the concept of similarity in metaphors. Ullman gives a definition of metaphor as a comparison between two things that are unified (direct) or direct comparison because the similarities/similarities are concrete or real. Because it is united, so it does not use comparative words[7]. The metaphor is basically created based on similarity between two units or between two terms, namely tenor and vehicle. Ullman calls tenor as the things we are talking about, and the vehicle is called the things that to which we are comparing it. That equation can be related to: (i) its physical form, (ii) its nature or character, or even (iii) one's perception[7]. In this study, metaphorical analysis, besides being supported by Ullman's theory, also uses the conceptual metaphorical approach developed by Lakoff \& Johnson (1980) previously described.

This study aims to analyze the metaphor symbol contained in the Javanese traditional expression. In addition to analyze the meaning of expression, the background of the culture influencing the creation of the expression is also elaborated since comprehend the meaning of expression as a whole requires the understanding about the context of Javanese culture. It is in line with what is stated by Saddhono that "Javanese people in their daily lives are not separable from Javanese culture, including the use of the language"[8]. By using in-depth meaning, it is expected to find out the content of local wisdom value in that traditional expression as the attempt to prevent Javanese cultural heritage as well as the sustainability of the Javanese tradition.

\section{METHOD}

This study examines the meaning of metaphorical symbols to know how the reflection of the value of local wisdom and the life principles of the Javanese people contained in the expression. The data in the form of qualitative data were obtained from informant and document data sources. From the informant's data sources, the researcher used skillful listening techniques, by collecting and collecting speeches that often used traditional forms of expression in the daily communication process in the Surakarta residency area, so that researchers could know their contextual meanings. In addition, data were obtained from documents, in the form of a collection of paribasan, bebasan, and saloka to obtain a complete description of the data. Data analysis techniques used interactive analysis[9], which flows between three components, including: data reduction, data presentation and conclusion drawing. If the determination of the conclusion is lacking, the researcher looks for the data again in order to perfect the conclusion.

\section{RESULT AND DISCUSSION}

This analysis focuses on the interpretation of the metaphorical symbols contained in Javanese traditional expressions. For a full explanation, the data is presented as follows. 
Table 1. Traditional Javanese Expressions

\begin{tabular}{lll}
\hline \multicolumn{1}{c}{ Aspect } & \multicolumn{1}{c}{ Expressions Form } \\
\hline $\begin{array}{l}\text { Traditional Javanese expressions } \\
\text { relating to the concept of relationship } \\
\text { with God }\end{array}$ & $\begin{array}{l}\text { Urip iki mung mampir ngombe } \\
\text { 'This life is only stopping by to drink' }\end{array}$ \\
\hline $\begin{array}{l}\text { Traditional Javanese expressions } \\
\text { relating to human principles as } \\
\text { individuals }\end{array}$ & $\begin{array}{l}\text { Anggone tutur, aja nganti Dhandhang diunekake Kuntul, } \\
\text { Kuntul diunekake Dhandhang } \\
\text { 'In speaking, do not let Dhandhang (black bird species) is } \\
\text { said to be Kuntul (white bird species), Kuntul (white bird } \\
\text { species) is said to be Dhandhang (black bird species)' }\end{array}$ \\
\hline $\begin{array}{l}\text { Traditional Javanese expressions } \\
\text { related to the concept of relationships } \\
\text { in the family }\end{array}$ & $\begin{array}{l}\text { Dadya pasangan kang rukun pindha mimi lan mintuna } \\
\text { 'Be a harmonious partner like mimi (a type of male crab) and } \\
\text { mintuna (a type of female crab)' }\end{array}$ \\
\hline $\begin{array}{l}\text { Traditional Javanese expressions } \\
\text { related to the concept of social relations } \\
\text { of the community }\end{array}$ & $\begin{array}{l}\text { Kanthi guyub rukun gugur gunung, bakal rampung } \\
\text { 'Byathering pillars of gugur gunung, (work) will be } \\
\text { completed' }\end{array}$ \\
\hline
\end{tabular}

\subsection{Metaphor symbols in traditional Javanese expressions relating to the concept of relationship with God.}

In life, Javanese people have the principle to be able to always maintain the balance of relations between one person and another, the natural world, and the relationship with God. In relation to God, Javanese society has a guideline that life in this world is not long/lasting. Human will die and there will be life after death, in retaliation for the results of their deeds in the world. This is implied in the phrase.

Figure 1. Correlation between the Source Domain and the Target

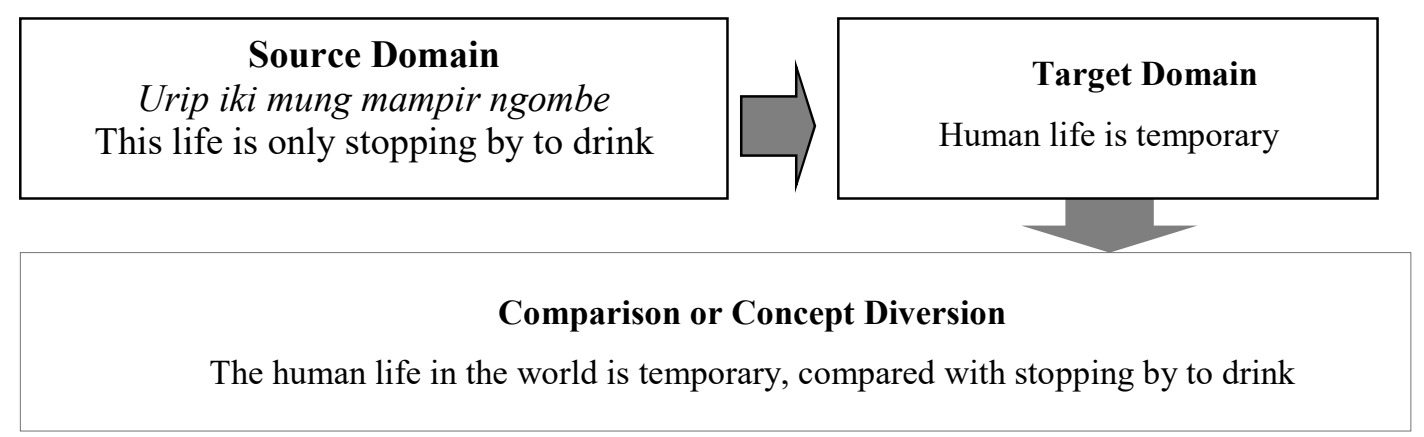

Based on the figure above, the expression can be understood that the life in the world is not long-lasting. This interpretation is based on the the relation of characteristic and the activity of mampir ngombe 'stopping by to drink' in which mampir ngombe 'stopping by to drink' is the characteristics of the activity that has no long period of time. 
The expression underlies the religious attitude of the Javanese people, who have the principle that our life in the world is not long or temporary and there will be an eternal life after death, so that this underlies a person to always do good, and be obedient to God.

The culture that can influence the creation of this parable is motivated by the long experience of Javanese society in ancient times, where they often moved/traveled long distances, both with their riding animals and on foot. When he is tired, he will stop by a place to just drink or eat, which is only for a short time, and then continue his journey. That experience is then concretized as the basis for the creation of that traditional expression.

\subsection{Metaphor symbols in traditional Javanese expressions relating to human principles as individuals}

Javanese people have local wisdom as an individual, that one must maintain attitude and actions, to be able to create a harmonious relationship between himself and God, and between individuals with each other in society. Therefore, one must have a good personality. A good person is an individual who can maintain attitudes and actions. One of them starts from words, because words can affect the merits of relations with each other. Thus the expression appears:

“Anggone tutur, aja nganti Dhandhang diunekake Kuntul, Kuntul diunekake Dhandhang”

'In speaking, do not let Dhandhang (black bird species) is said to be Kuntul (white bird species), Kuntul (white bird species) is said to be Dhandhang (black bird species).'

This expression contains the classification of animal names as a symbol of metaphor or comparison. The source domain is a color symbol that exists in both types of birds, while the target is the nature possessed by something that concerns good and bad symbolized by the two colors. The black color possessed by the Dhandhang bird, contains a symbol of something bad/not good, while the white color of Kuntul has a symbol of something good. The expression implies that someone is accustomed to saying according to reality or in other words not manipulating. Not letting something good is said to be bad, or something bad is said to be good. This interpretation is based on the nature / physical characteristics of the two birds. Each is used as a symbol that can represent disclosure of a good and a bad thing. The expression also contained a mandate for the Javanese people to have the principle of perseverance in defending the truth.

The creation of these expressions can be related to the concept of Javanese society relating to animal mythology, as does the black crow. For Javanese people crows are believed to contain a mystical thing. For example, crows that continue to ring and swirl can give a sign that there will be death, disaster or something that is bad that will happen around the place. This is then reflected in traditional expressions, with black animal symbols being a symbol of something that is not good.

\subsection{Metaphor symbols in traditional Javanese expressions related to the concept of relationships in the family.}

In building family harmony, one of the concepts adopted by Javanese people is that husbands and wives can gather into one roof or not apart. Therefore in the Javanese culture the proverb appears 


\section{"Dadya pasangan kang rukun pindha mimi lan mintuna”}

'Be a harmonious partner like mimi (a type of male crab) and mintuna (a type of female crab)'

The metaphorical expression compares two things, namely 'couple (husband and wife)' as tenors, and the type of animal mimi and mintuna as its property. Mimi and mintuna are male and female crabs. Both animals have the nature that if its walk it will walk together with its partners. For the Javanese people the nature possessed by the two animals is used as a symbol of harmony. The concept is further embodied in the phrase, in the form of advice to husband and wife, during the wedding ceremony, so that they can always live in harmony together. Together can be interpreted as together in joy and sorrow, together in one roof, as well as other togetherness concepts that can support family harmony.

\subsection{Metaphor symbols in traditional Javanese expressions related to the concept of social relations of the community.}

As part of community members, Javanese people always want to maintain good relations with their social environment. This can be reflected in the nature of Javanese who love to work together in carrying out work for the common good. So the phrase:

"Kanthi guyub rukun lan gugur gunung, bakal rampung"

'By gathering pillars and gugur gunung, (work) will be completed '

The expression contains a comparison symbolized by the phrase 'fall mountain'. The use of the form 'fall mountain' is a source domain that contains the meaning of mutual cooperation. "fall" means dead, collapsed. This is to symbolize something that collapses or finishes. Whereas 'Mountain' is a symbol of a large or number of works. So that the expression means that a large or a lot of work will be lighter, quickly completed and finished, if done together.

The interpretation of the metaphor is based on the common traits that exist in objects that are used as symbols. The representation of the concept of ideas in these expressions is manifested in a variety of living activities of Javanese people which are based on mutual help and cooperative in the community. For the Javanese community, take and give is one aspect of realizing social welfare.

\section{CONCLUSION}

Metaphors are built through similarity concepts without comparative words, so they often use symbols or symbols such as animals, collisions or humans. Meaningful efforts can be made by describing the structure of the metaphor based on Ullman's theory, on the tenor and medium. Furthermore, relationships identified show similarities between the source and target domains. The relation can be based on the similarity of traits, characteristics, circumstances, and activities that exist in humans, animals, plants and objects around them. With this meaning, it will be easier for someone in understanding traditional Javanese expressions that are rich in cultural values of local wisdom. 


\section{REFERENCE}

[1] S. Endraswara, Etnologi Jawa (Penelitian, Perbandingan, Dan Pemaknaan Budaya). Yogyakarta: CAPS (Center For Academic Publishing Service), 2015.

[2] W. Lixia, "A cognitive analysis of snake and lion metaphors in Mandarin Chinese and British English,” GEMA Online ${ }^{T M}$ J. Lang. Stud., vol. 12, no. January, pp. 195-196, 2012.

[3] R. Vengadasamy, "Metaphors as ideological constructs for identity in Malaysian short stories," 3L Lang. Linguist. Lit., vol. 17, pp. 99-107, 2011.

[4] D. Nirmala, "Proses Kognitif dalam Ungkapan," Parole, vol. 4, no. 1, pp. 1-13, 2014.

[5] B. Herusatoto, Simbolisme dalam Budaya Jawa. Yogyakarta: Hanindita Graha Widia, 2005.

[6] J. Danandjaja, Folklor Indonesia: ilmu gosip, dongeng dan lain-lain. Jakarta: Grafiti Press, 1992.

[7] E. Subroto, Pengantar Studi Semantik dan Pragmatik. Surakarta: Cakrawala Media, 2011.

[8] K. Saddhono, "Cultural and social change of foreign students in Indonesia: The influence of Javanese Culture in Teaching Indonesian to Speakers of Other Languages (TISOL)," IOP Conf. Ser. Earth Environ. Sci., vol. 126, no. 1, pp. 1-8, Mar. 2018.

[9] M. B. Miles and A. M. Huberman, Qualitative data analysis: An expanded sourcebook. Thousand Oak, CA: Sage, 2007. 